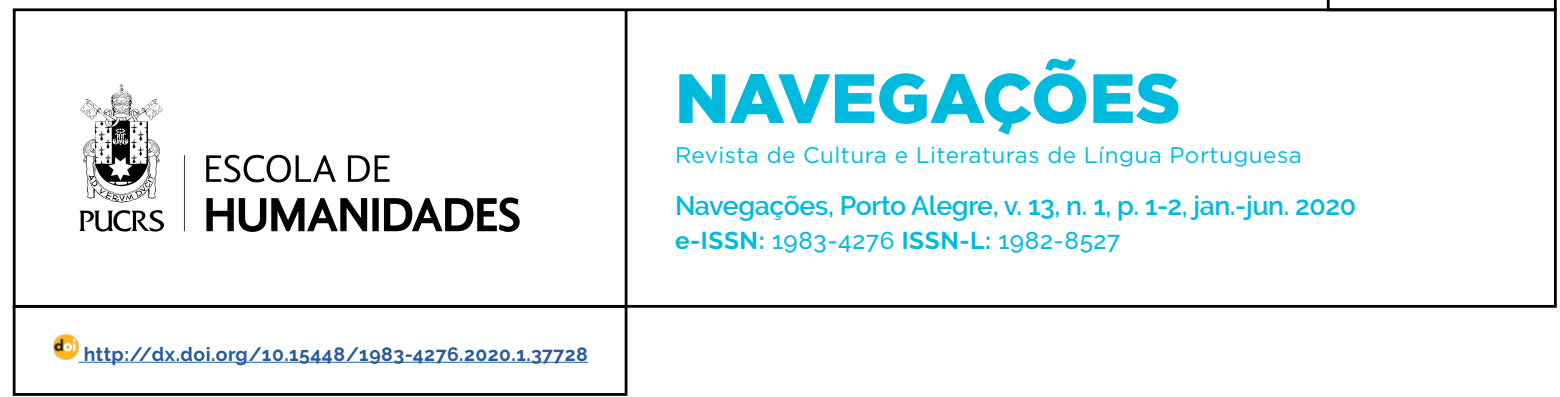

SEÇÃO: RESENHAS

\title{
ESPANCA, Florbela. Diário; O Dominó Preto. Organização, fixação crítica dos textos e notas de Fabio Mario da Silva. Lisboa: Edições Esgotadas, 2019.
}

\section{Danielle Meireles de \\ Andrade ${ }^{1}$ \\ orcid.org/0000-0003-1321-764X \\ dani.mddeandrade@gmail.com}

\section{Henrique Marques \\ Samyn ${ }^{1}$}

orcid.org/0000-0002-2624-3487

marquessamyn@gmail.com

Recebido em: 16 abr. 2020

Aceito em: 17 mai. 2020.

Publicado em: 10 ago. 2020
Publicado como parte das obras completas de Florbela Espanca (18941930), o volume contendo o Diário e O Dominó Preto tem por objetivo, segundo Fabio Mario da Silva - responsável pela organização, notas e fixação de textos - respeitar ao máximo o desejo da poetisa. Algumas edições anteriores destas obras não seguiam a sua vontade, alterando, obstruindo e até mesmo prejudicando sua qualidade literária. Já esta nova edição traz comentários de especialistas se dedicam ao estudo sobre a produção literária e a vida de Florbela Espanca, enriquecendo a visão do leitor e contemplando a fortuna critica sobre a autora.

Produzido entre 11 de janeiro e 2 de dezembro de 1930, o Diário de Florbela é publicado com grafia e acentuação atualizadas, mas a pontuação é mantida conforme a edição de 1931. Nota-se a preocupação em manter os detalhes que caracterizam a sua escrita, respeitando a vontade da autora, como anteriormente mencionado. Isa Margarida Vitória Severino comenta que há no Diário a busca de uma identidade, assinalando:

\begin{abstract}
o « eu» diarístico obedece, por um lado, ao impulso de anotar as impressões diárias, de modo espontâneo e mesmo negligente, sem quaisquer preocupações de escrita compartilhável e sem arrazoamentos. Por outro lado, evidencia a intenção que subjaz à vivência dos dias, ou seja, a de recolher a panóplia de «reflexões, impressões, ideias, maneira de ver e sentir» que the confere uma identidade valorativa e o distingue dos demais [...] (SEVERINO, 2019, p. 38).
\end{abstract}

Severino observa que há uma proximidade entre o Diário e a obra poética da autora portuguesa. A pesquisadora aponta ainda as similaridades temáticas e as conhecidas dificuldades, perceptiveis tanto na diarística quanto na obra poética, de Florbela chegar a afirmações definitivas sobre quem ela seria, o que evidencia os embates da autora consigo mesma, em torno do "eu": ora ela coloca em suas obras características que a exaltam, ora se questiona, colocando-se de maneira negativa e deslocada no que tange ao padrão que seria considerado o ideal para as mulheres de sua época. Portanto, é possivel notar a ambiguidade tanto na produção poética quanto na sua produção diarística. 
Na edição dos poemas de Florbela Espanca preparada por Maria Lúcia Dal Farra (1999), a especialista afirma que, no Livro de "Soror Saudade" (1923), a sua busca por si mesma ainda era algo vago: não tendo qualquer certeza sobre sua identidade, Florbela indagava, perguntava e refletia sobre sua individualidade, mas também fazia questionamentos sobre seu papel cultural e social na sociedade portuguesa em que estava inserida. Como já referido, a poetisa lusitana transfere esses questionamentos para o Diário. A esse propósito, pode-se ainda observar que considerava que "a grande literatura era de natureza confessional, um derramar de alma nua e escrita", como observa Cláudia Pazos Alonso (1997, p. 64).

Já no livro de contos O Dominó Preto resulta de uma obra em prosa que Florbela preparava para publicação em 1927 - projeto suspenso devido à morte de seu irmão Apeles - o que ensejaria a preparação de outro volume de contos, As Máscaras do Destino. Em decorrência disso, 0 Dominó Preto só seria publicado mais de meio século depois, por razões que ainda são objeto de discussão entre especialistas. Reunindo textos já publicado em periódicos (como "À margem de um soneto" e "O Dominó Preto") e narrativas inéditas, a obra não deixa de evidenciar o seu olhar crítico acerca da condição social feminina questão abordada no estudo introdutório assinado por Fabio Mario da Silva. Evidenciando papéis sociais e estereótipos determinados por valores patriarcais, a ficção florbeliana propõe inversões e subversões que suscitam questionamentos acerca dos lugares que as mulheres - forçadamente deveriam ou não ocupar.

Tema fulcral nos escritos de Florbela - tanto a lírica como a ficcional -, a busca pelo "eu" ressurge em O Diário e O Dominó Preto; é a partir dessa procura que a autora repensa seu lugar e o lugar das outras mulheres. Desse modo, a publicação deste mais recente volume das obras completas vem demonstrar a atualidade da produção literária florbeliana, em tempos nos quais o enfrentamento das estruturas que perpetuam a dominação masculina se faz particularmente necessário.

\section{Referências}

ALONSO, Cláudia Pazos. Imagens do eu na poesia de Florbela Espanca. Lisboa: Imprensa Nacional-Casa da Moeda, 1997.

ESPANCA, Florbela. Poemas. Estudo Introdutório, Organização e Notas de Maria Lúcia Dal Farra. São Paulo: Martins Fontes, 1999.

ESPANCA, Florbela. Diário; O Dominó Preto. Organização, fixação crítica dos textos e notas de Fabio Mario da Silva. Lisboa: Edições Esgotadas, 2019.

SEVERINO, Isa Margarida Vitória. A Construção da Persona no Diário de Florbela Espanca. In: ESPANCA, Florbela. Diário; O Dominó Preto. Organização, fixação critica dos textos e notas de Fabio Mario da Silva. Lisboa: Edições Esgotadas, 2019.

SILVA, Fabio Mario da. Algumas facetas femininas. Uma leitura dos contos de O Dominó Preto, de Florbela Espanca. In: ESPANCA, Florbela. Diário; O Dominó Preto. Organização, fixação crítica dos textos e notas de Fabio Mario da Silva. Lisboa: Edições Esgotadas, 2019

\section{Endereço de correspondência}

Danielle Meireles de Andrade

Universidade do Estado do Rio de Janeiro. Instituto de Letras.

Rua São Francisco Xavier, 524. $11^{\circ}$ andar. Bairro Maracanã. Rio de Janeiro, RJ.

Henrique Marques Samyn

Universidade do Estado do Rio de Janeiro. Instituto de Letras.

Rua São Francisco Xavier, 524.11ªndar. Bairro Maracanã 